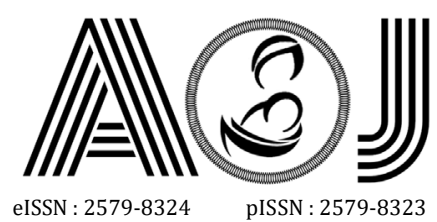

eISSN : 2579-8324

pISSN : 2579-8323

\title{
RESEARCH
}

\section{The Difference of Using Antibiotics Before and After Antimicrobial Resistance Control Program (PPRA) at RSUP Dr. M. Djamil Padang}

Ermawati ${ }^{1}$, Daan Khambri ${ }^{2}$, Dedy Almasdy ${ }^{3}$

Affiliation author: 1. Masters Program Faculty of Public Health Institute of Andalas University, Lecture of Public Health Institute of Andalas University; 2. Subdivision of Oncology, Surgery Department, Faculty of Medicine, Andalas University, Dr. M. Djamil Central General Hospital Padang; 3. Clinical Pharmacy Department, Faculty of Pharmacy, Andalas University, Dr. M. Djamil Central General Hospital Padang

Correspondence to: Ermawati,email: erma2812@yahoo.com,Hp: 08116620861

\section{Abstract}

Antibiotics have been proven to be beneficial for human life since their discovery. This type of drug is the most widely used in infections caused by bacteria. the function is to inhibit growth or kill microorganisms. Therefore, more than 30-80\% of patients in developed countries who are hospitalized receive antibiotics, either alone or in combination. Evaluating the implementation of PPRA at RSUP. Dr. M. Djamil by comparing the evaluation of antibiotic use before and after the application of PPRA in inpatients in the Obgyn.

We conducted this research including a type of correlational analytical research with a retrospective approach. The research sample was taken by the Medical Record room of the RSUP. Dr. M. Djamil Padang. The research was carried out for 1 month, from May 1 to May 31, 2020. The population in this research was all inpatients of Obstetrics and Gynecology in Dr. M. Djamil Padang.

There was an increase in the percentage of antibiotic use in 2019 in line with the higher percentage of surgery in 2019 compared to 2018. As regulated by the guidelines for the use of antibiotics in Dr. M. Djamil, for surgery, prophylactic antibiotics are given 30 minutes before the procedure to prevent infection due to the invasive action. The use of prophylactic antibiotics whether to continue is determined by the type of operation, the length of the operation, the amount of bleeding during the operation, the clinical patient, the laboratory value.

There were no significant changes in the implementation of PPRA's work on the qualitative analysis of antibiotic use.

Keywords: Antibiotics, PPRA, Evaluation

\section{INTRODUCTION}

The evaluation on antimicrobial resistance control program in hospital is conducted through antibiotic usage evaluation ad monitoring on the emergence and spread of multiresistant microbes. Evaluation of the use of antibiotics can be conducted by two methods, quantitative and qualitative. Quantitative antibiotic evaluation is carried out based on the 


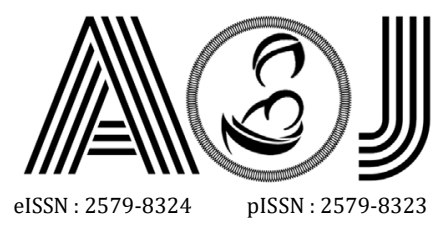

value of Defined Daily Doses (DDD), while qualitatively is presented by assessing the appropriateness of antibiotic use using the Gyssen line. ${ }^{3}$

RSUP Dr. M. Djamil is national referral hospital located in Padang City. This hospital has received the status of passing international accreditation from the Hospital Accreditation Committee (KARS). Following the Regulation of the Minister of Health of the Republic of Indonesia Number 8 Year 2015, every hospital must implement PPRA optimally. RSUP Dr M Djamil has implemented this program since 2018.

The implementation of this program began with a vertical survey of 8 governmentselected hospitals in 2016. This survey involved four basic services, such as the obstetrics and gynecology section (Obgyn). From these results, $62 \%$ of inpatients used antibiotics whose type and duration of use were not supported by complete laboratory results that did not meet the standards of Minister of health regulations Number 2406 of 2011. ${ }^{4}$

In 2018, RSUP Dr. M Djamil through the PPRA Team had compiled a Guide to Using Antibiotics and started running in mid-2018. Therefore, researchers are interested in knowing the effect of this program on the quantity and quality of antibiotic use in the Obgyn section by comparing before and after usage. ${ }^{5}$

\section{RESEARCH PROBLEM}

Based on the problems above, research problem in this research is "What is the description of the characteristics of antibiotic use in inpatients at the Obgyn of RSUP/ Dr. M. Djamil Padang before the implementation of PPRA?"

\section{RESEARCH OBJECTIVE}

This research aims to find out the implementation of PPRA at RSUP De. M Djamil by looking at the differences in antibiotic use before and after PPRA implementation in inpatients in the Obgyn department.

\section{RESEARCH METHOD}

We conducted the research of correlational analytic research type with retrospective approach. The research sample was taken by the Medical Record room of the RSUP. Dr. M. Djamil Padang. The research was conducted for 1 month, from May 1 to May 31, 2020. The population in this study were all inpatients of Obstetrics and Gynecology in Dr. M. Djamil Padang. 


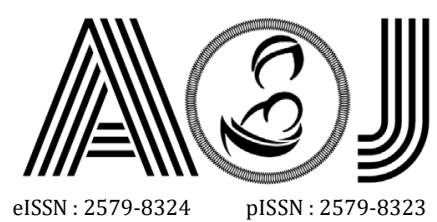

eISSN : 2579-8324
pISSN : 2579-8323

Editorial Room Andalas Obstetrics and Gynecology Journal, $3^{\text {rd }}$ floor of KSM of Obstetrics and Gynecology,

RSUP DR. M. Djamil Padang, Jl. Perintis Kemerdekaan Padang, Sumatera Barat 25127

http://jurnalobgin.fk.unand.ac.id/index.php/JOE

\section{RESULT OF THE RESEARCH}

\section{Respondents' Characteristic}

Based on this research, The number of patients who went home in the obstetrics department from January 12018 to March 312018 was 760 patients and on January 12018 to March 312019 was 785 patients. Sampling was conducted by simple random sampling where each period was sampled as many as 212 patients.

\section{Age}

Based on Table 1, it is found that the most age group was the 30-40 with a percentage of 34\% in the period 1 January 2018 - 31 March 2018 and 38\% in the period 1 January 2018 31 March 2019. The next sequence was the 20-30 year age group with a percentage of $33 \%$ in the period 1 January 2018 - 31 March 2018 and 38\% in the period 1 January 2018 - 31 March 2019. Meanwhile, the least age group was under $20(1 \%)$ and $>60$ years old (1\%) in the 2019 period Meanwhile, in 2018, the minimum age group was $>60$ years of 9 people (4\%).

Table 1. Respondent based on Age Group

\begin{tabular}{lllll}
\hline Age Group & \multicolumn{2}{l}{$\mathbf{2 0 1 8}$} & \multicolumn{2}{c}{$\mathbf{2 0 1 9}$} \\
\cline { 2 - 5 } & $\mathrm{f}$ & $\%$ & $\mathrm{f}$ & $\%$ \\
\hline$<\mathbf{2 0}$ years & 14 & $\mathbf{7 \%}$ & 3 & $1 \%$ \\
\hline $\mathbf{2 0 - 3 0}$ years & 71 & $33 \%$ & 81 & $38 \%$ \\
\hline $\mathbf{3 0 - 4 0}$ years & 72 & $34 \%$ & 81 & $38 \%$ \\
\hline $\mathbf{4 0 - 5 0}$ years & 35 & $17 \%$ & 31 & $15 \%$ \\
\hline $\mathbf{5 0 - 6 0}$ years & 11 & $5 \%$ & 13 & $6 \%$ \\
\hline $\mathbf{5 0}$ years & 9 & $4 \%$ & 3 & $1 \%$ \\
\hline Total & 212 & $100 \%$ & 212 & $100 \%$ \\
\hline
\end{tabular}

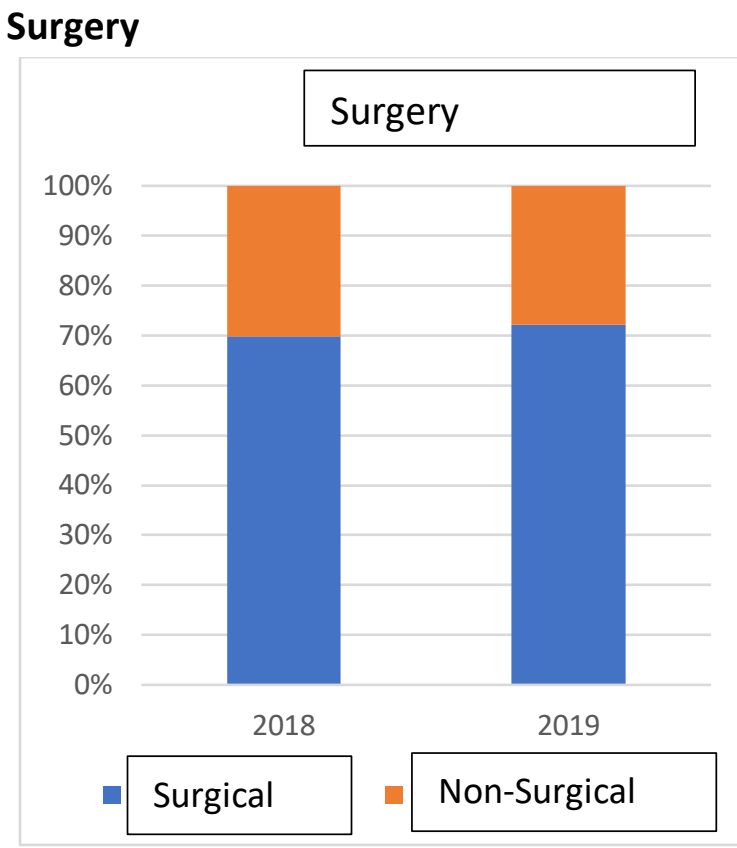

Figure 1. Surgery-based chart

Based on the Figure 1, it is seen that most patients admitted to the Obgyn ward were treated with surgery. In 2018, there were 148 patients (70\%) operated and in 2019 of 153 (72\%). 


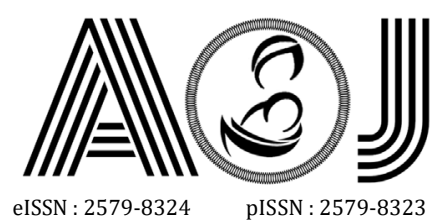
ANDALAS OBSTETRICS AND GYNECOLOGY JOURNAL Address for Correspondence:

Editorial Room Andalas Obstetrics and Gynecology Journal, $3^{\text {rd }}$ floor of KSM of Obstetrics and Gynecology, RSUP DR. M. Djamil Padang, Jl. Perintis Kemerdekaan Padang, Sumatera Barat 25127

Website:

http://jurnalobgin.fk.unand.ac.id/index.php/JOE

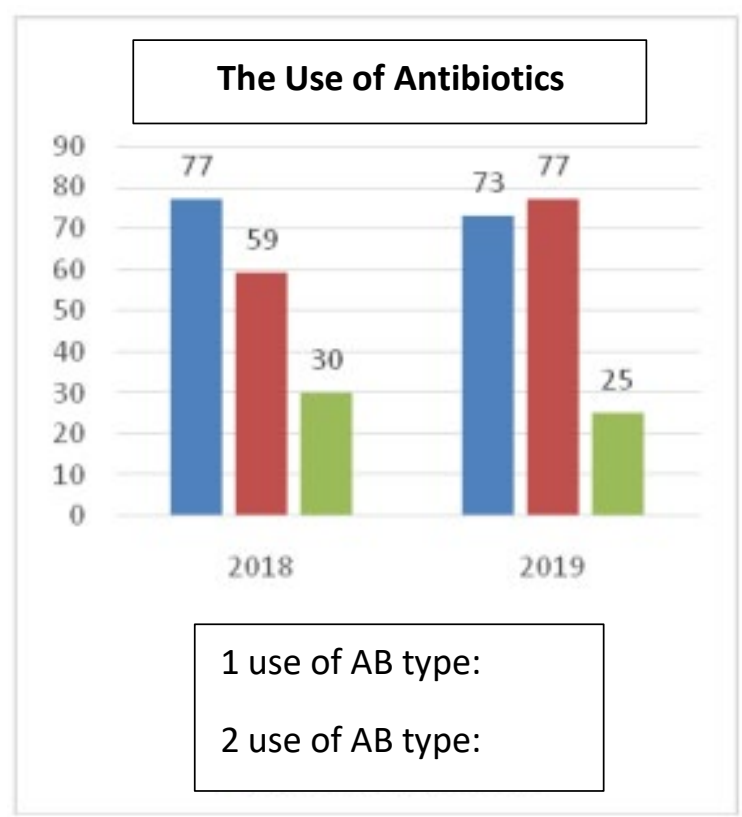

Figure 2. Chart of Antibiotics Use

\section{The Use of Antibiotics Therapy}

In Figure 2, it is seen that in 2018, the dominant use of antibiotics only used 1 type of antibiotic, there were 77 patients or $46 \%$ of the total antibiotic use. The use of 2 types of antibiotics were 59 patients (36\%) and 3 types of antibiotics were 30 patients (18\%), while in 2019, 77 patients were dominant using 2 types of antibiotics or $44 \%$ of the total use of antibiotics. The use of 1 type of antibiotic were 73 patients (42\%) and 3 types of antibiotics of 25 patients (14\%).

\section{Evaluation of Antibiotics Usage Quantitatively}

Evaluation or study of antibiotic use was performed in all patients. Based on the results of quantitative analysis of antibiotic use using the ATC/DDD system in samples of adult categories who received antibiotic therapy during treatment can bee seen in the picture in table 5.2 for the period January - March 2018 and January - March 2019. 


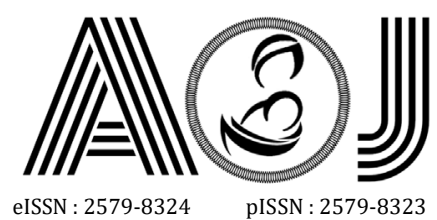

eISSN : 2579-832
pISSN : 2579-8323

Editorial Room Andalas Obstetrics and Gynecology Journal, $3^{\text {rd }}$ floor of KSM of Obstetrics and Gynecology,

RSUP DR. M. Djamil Padang, Jl. Perintis Kemerdekaan Padang, Sumatera Barat 25127

Website:

http://jurnalobgin.fk.unand.ac.id/index.php/JOE

Table 2. Antibiotic Use

\begin{tabular}{ccccccc}
\hline Antibiotik & Kode & DDD & \multicolumn{2}{c}{2018} & \multicolumn{2}{c}{2019} \\
\cline { 3 - 7 } & & & $\begin{array}{c}\text { Total } \\
\text { penggunaan } \\
(\mathrm{g})\end{array}$ & $\begin{array}{c}\text { DDD/ } \\
100\end{array}$ & $\begin{array}{c}\text { Total } \\
\text { penggunaan } \\
(\mathrm{g})\end{array}$ & $\begin{array}{c}\text { DDD/ } \\
100\end{array}$ \\
\hline Ceftriaxone & J01DD04 & 2 & 1022 & 46,45 & 1069 & 49,63 \\
\hline Cefixime & J01DD08 & 0,4 & 48,2 & 10,95 & 115,6 & 26,83 \\
\hline $\begin{array}{c}\text { Cefoperazone } \\
\text { JolDD12 }\end{array}$ & 4 & 10 & 0,23 & 4 & 0,09 \\
\hline $\begin{array}{c}\text { Levofloxacin } \\
\text { (Parenteral) }\end{array}$ & J01MA12 & 0,5 & 0,75 & 0,14 & 0,75 & 0,14 \\
\hline $\begin{array}{c}\text { Metronidazole } \\
\text { (Parenteral) }\end{array}$ & J01XD01 & 1,5 & 85,5 & 5,18 & 40,2 & 2,49 \\
\hline $\begin{array}{c}\text { Metronidazole } \\
\text { (Oral) }\end{array}$ & P01AB01 & 2 & 127,08 & 5,78 & 36,6 & 1,7 \\
\hline $\begin{array}{c}\text { cloramphenicol } \\
\text { J01BA01 }\end{array}$ & 3 & 36 & 1,09 & & \\
\hline $\begin{array}{c}\text { Ciprofloxacin } \\
\text { (Oral) }\end{array}$ & J01MA02 & 1 & & & 5,5 & 0,51 \\
\hline \begin{tabular}{c} 
Clindamycin \\
\hline
\end{tabular} & J01FF01 & 1,2 & & & 8 & 0,62 \\
\hline
\end{tabular}

Based on Table 2, it is seen that the most antibiotic use in the Obgyn for the period January - March 2018 and January - March 2019 was ceftriaxone with a value of 46.45 DDD /100 patient days in 2018 and 49.63 DDD/ 100 patient days in the 2019 period. This value was far higher than other antibiotics. The least antibiotic use in 2018 was levofloxacin parenteral with DDD/100 patient day value 0.14 and in 2019 was also parenteral levofloxacin with $\mathrm{DDD} / 100$ patient day value of 0.14 .

The value of Ceftriaxone was much higher than the value of cefixime, that was the second most widely used antibiotic in this study with values of $10.95 \mathrm{DDD} /$ patient days in 2018 and 26.83 DDD/100 patient days in 2019, respectively.

\section{Evaluation of Antibiotics Usage Qualitatively}

Antibiotics usage qualitatively was evaluated using Gyssens criteria that wasdivided into 0 - VI categories. 


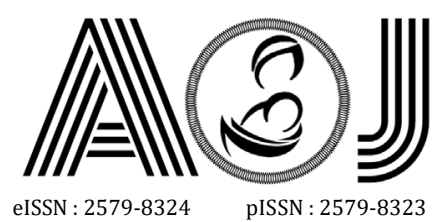

eISSN : 2579-8324

Editorial Room Andalas Obstetrics and Gynecology Journal, $3^{\text {rd }}$ floor of KSM of Obstetrics and Gynecology,

RSUP DR. M. Djamil Padang, Jl. Perintis Kemerdekaan Padang, Sumatera Barat 25127

Website:

http://jurnalobgin.fk.unand.ac.id/index.php/JOE

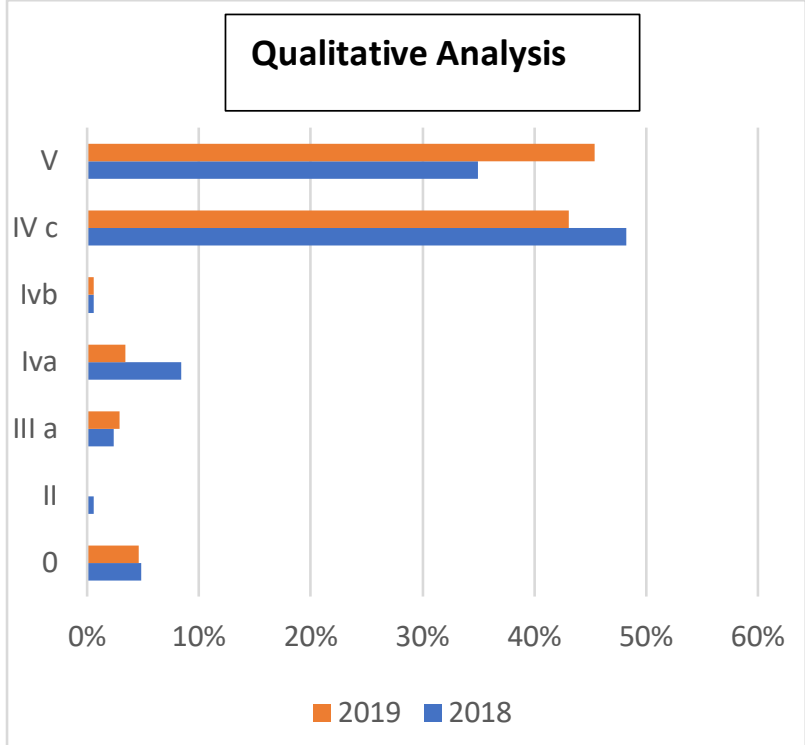

Figure 3. Qualitative Analysis of Antibiotic Use

From Figure 3, 166 samples in 2018 and 174 samples in 2019, the most categories were V and IV C. In 2018, the most categories were category IV C with $48 \%$, followed by category V with $35 \%$. In 2019 , the most categories were category $V$ with $45 \%$ followed by IVC category with $43 \%$.

\section{DISCUSSION}

\section{The General Depiction of Result}

Age

In this research, it is found that the age groups that were most prevalent in both periods were the 30-40 age group and the 20-30 year age group. This was obtained because in the Obgyn ward, there were predominant patients with obstretric cases that could occur in women of childbearing age, in which women with reproductive conditions were still functioning properly, namely between the ages of $15-49$ years. ${ }^{6}$

\section{The Use of Antibiotic Therapy and Surgical Measures}

More than half of the patients treated in the Obgyn both in 2018 and 2019 used antibiotics, and there was an increase in the percentage of antibiotic use in 2019 compared to 2018. The large number of antibiotic use was due to the high operative administration in the Obgyn ward. Operational action in 2018 was $70 \%$ and $72 \%$ in 2019.

There was increase in the percentage of antibiotic use in 2019. It was in line with the higher percentage of surgery in 2019 compared to 2018. As regulated by the guidelines for the use of antibiotics in Dr. M. Djamil, for surgery, prophylactic antibiotics are given 30 


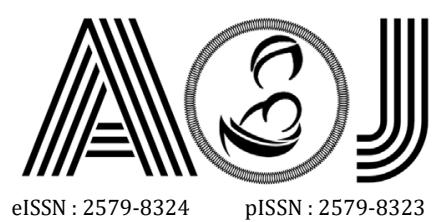

eISSN : 2579-8324
pISSN : 2579-8323

minutes before the procedure to prevent infection due to the invasive action. The use of prophylactic antibiotics whether to continue is determined by the type of operation, the length of the operation, the amount of bleeding during the operation, the clinical patient, the laboratory value.

\section{The Combination of Antibiotic Usage}

In 2018, dominant antibiotic used1 type. In 2019, the dominant patient used 2 types of antibiotics. The use of these 2 types of antibiotics occurred because of a shift in peripheral antibiotics to oral antibiotics. There were rules for the use of antibiotics Dr. M. Djamil, that has been implemented since the existence of PPRA such as the limitation of the length of time using parenteral antibiotics. Thus patients who had received parenteral therapy exceed their usage allowance continued with other types of antibiotics or oral. In this research, it was seen that the number of cefixime antibiotics was given after the use of ceftriaxone antibiotics for 3 days. $^{7}$

\section{The Evaluation of Antibiotic Usage}

\section{Quantitative Evaluation}

Quantitative antibiotic use was assessed by calculating the DDD (Define Daily Dose) 100 patien days recommended by WHO. DDD is a unit of measurement independent of price and drug formulation, but an independent unit of measurement that reflects global doses independent of genetic variation, making it possible to assess drug consumption trends and compare between population groups or health care systems. Prescription data presented in DDD/100 patient days can provide a rough estimate of the proportion of hospital patients given antibiotics. ${ }^{8}$

From the results of the antibiotic quantity assessment shown in the table, it can be seen that Ceftriaxone is the most widely used antibiotic with a value of 46.45 DDD / 100 patient days in 2018 and 49.63 DDD / 100 patient days in the 2019 period, with DDD values based on WHO are 2, which means that out of 100 people, 46 patients in the obgyn ward received ceftriaxone 2 grams per day in the January-March 2018 period and 49 obgyn ward patients received ceftriaxone 2 grams per day in the January-March 2019 period. 2019 compared to 2018 due to the high percentage of surgery performed in 2019. ${ }^{9}$ The use of antibiotics given as prophylaxis in this period was cefriaxone, and its use was continued during treatment, so that the quantitative use of cefrtriaxone tends to be higher. ${ }^{5}$

From the results of the antibiotic quantity assessment shown in the table, it can be seen that Ceftriaxone was the most widely used antibiotic with a value of $46.45 \mathrm{DDD} / 100$ patient days in 2018 and 49.63 DDD/100 patient days in the 2019 period, with DDD values based on WHO are 2. It means that out of 100 people, 46 patients in the obgyn ward received 


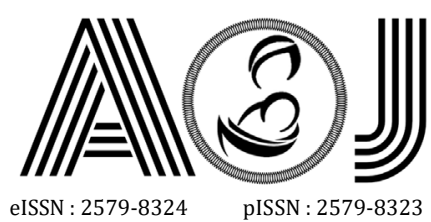

eISSN : 2579-8324

pISSN : 2579-8323

ceftriaxone 2 grams per day in the January-March 2018 period and 49 obgyn ward patients received ceftriaxone 2 grams per day in the January-March 2019 period. 2019 compared to 2018 due to the high percentage of surgery performed in 2019. The use of antibiotics given as prophylaxis in this period was cefriaxone, and its use was continued during treatment, therefore, the quantitative use of cefrtriaxone tends to be higher.

This research was inline with AMRIN study (2005) conducted at RS Dr. Soetomo Surabaya and dr. Kariadi Semarang, who received the largest data on antibiotic prescribing in the surgical ward, came from the third generation cephalosporin group of 16.4 DDD / 100 days of hospitalization. ${ }^{10}$ Based on Yuniftiadi's (2010) research, it is also known that the use of antibiotics in the Intensive Care Unit at dr. Kariadi Semarang, found that ceftriaxone was the most widely used drug, amounting to $62.2 \mathrm{DDD} / 100$ patients. ${ }^{11}$ Likewise with Febiana's research (2011) on the pediatric ward of dr. Kariadi Semarang, the use of antibiotics comes from the cephalosporin class, such as cefrianxone with a total use of 39.4 DDD / 100. ${ }^{12}$

The high use of ceftriaxone antibiotics is based on the guidelines for the use of antibiotics in Dr. M. Djamil (2018), ceftiaxone is the first line antibiotic. It is an antibiotic that can be prescribed by all doctors who work at RSUP DR. M. Djamil Padang. There is no limit to that patients can get ceftriaxone, and how much to give. Ceftriaxone usage will only be reviewed if it is used for more than 7 days. ${ }^{5}$

Ceftriaxone is the most commonly used antibiotic due to its high antibacterial potency, broad spectrum of activity and low potential for toxicity. The most likely reasons for its widespread use are effectiveness in organisms susceptible to complex and uncomplicated urinary tract infections, respiratory tract infections, skin, soft tissue, bone and joint infections, bacteremia/septicemia, pneumonia, meningitis, infections in immunosuppressed patients acute bacterial otitis media, genital infections, disseminated disease and in surgical prophylaxis infection. ${ }^{13}$

In contrast to what Andriani (2016) did at RSUP M. Djamil, in which the most widely used antibiotic in the Obgyn ward is Cefoperazone. This difference could be due to the revision of the guidelines for the use of antibiotics in Dr. M. Djamil, in which the latest guidelines for the use of antibiotics were published in 2018, and the antibiotic used as surgical prophylax is cefazolin or ceftriaxone and therapy for sectio caesaria surgery wound infection is cefriaxone. ${ }^{14}$

Ceftriaxone is a third generation semisynthetic cephalosporin with a long half-life. Thus, it was given once a day. It was administered intravenously or intramuscularly and had a wide spectrum of activity against Gram-positive and Gram-negative aerobics, and some anaerobic bacteria. Ceftriaxone activity is generally greater than the first and second generation cephalosporins against Gram-negative bacteria, but lower against Gram-positive bacteria. 


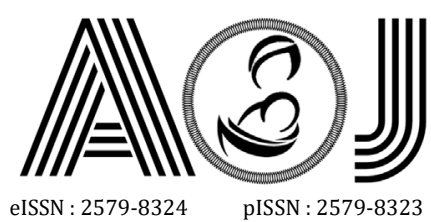

eISSN : 2579-8324
pISSN : 2579-8323

Ceftriaxone is generally more active than cefoperazone except against Pseudomonas aeruginosa, and was similar in activity to cefotaxime and moxalactam..$^{15}$

The use of cefixime in 2019 was higher than in 2018 due to a policy that was enforced after the implementation of PPRA, in which there were restrictions on the length of time using parenteral antibiotics such as ceftriaxone. After administration of the antibiotic ceftriaxone, it was followed by cefixime, that led to a higher rate of cefixime antibiotic use. ${ }^{16}$

Cefixime was a third generation cephalosporin, in the same way that ceftriaxone by the oral route has become an increasingly important first-line choice in the treatment of common bacterial infections. Cefixime is very stable in the presence of the beta-lactamase enzyme. Many organisms that are resistant to penicillin and some cephalosporins due to the presence of beta-lactamases, will be susceptible to cefixime. ${ }^{17}$

The next antibiotic that is quite high is metronidazole. Metronidazole divided into parenteral and oral administration. In 2018, oral metronidazole administration was higher than parenteral administration, whereas in 2019, the administration of metronidazole was higher parenterally. Metronidazole is one of the drugs of choice for the treatment of anaerobic bacterial infections, protozoan infections, and microaerophilic bacterial infections. Metronidazole was cytotoxic against facultative anaerobic microorganisms. Conversion to oral therapy with ciprofloxacin/metronidazole is as effective as continued intravenous therapy with oral ceftriaxone and metronidazole in patients who can tolerate oral administration. Studies of patients undergoing elective colon surgery showed that there was no significant difference whether metronidazole was administered intravenously or orally as prophylaxis. ${ }^{18}$

\section{Qualitative Evaluation}

The quality of the use of antibiotics was assessed using the Gyssens criteria consisting of 13 criteria. Rational antibiotic use was categorized into group 0 , and irrational antibiotic use was categorized into groups 1- VI. ${ }^{3}$

Category VI in this research did not exist, because all incomplete medical records were excluded from the start of sample selection. All cases had laboratory results and diagnostic data, but only 1 of all patients had data on bacterial culture results to see antibiotic sensitivity to certain bacteria. Thus, if it was based on the completeness of the data, almost all of the medical records of patients in this research would be entered in category VI (incomplete data). To be able to further assess the accuracy of antibiotic use, complete data from all patient medical records must have all categories of gyssens (there are indications of antibiotic administration, antibiotic dose data, duration of antibiotic administration, drug administration interval). ${ }^{19}$ 


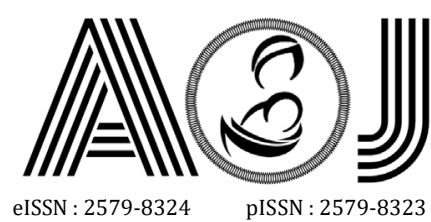

eISSN : 2579-8324
pISSN : 2579-8323

In this research, there was an increase in the percentage of category $V$ in 2019 compared to 2018. It means that there is an increase in the use of antibiotics that are not indicated. The use of antibiotics that did not match the indications mostly occurred because of the continued administration of antibiotics after prophylactic antibiotics without any indication, whether it was the type of surgery, the results of laboratory tests or clinical conditions. Patients who underwent clean surgery, in the rule, should be given prophylactic antibiotics 30 minutes before the procedure using third-generation cephalosporin antibiotics, ceftazidine as an option, and can be an alternative to ceftriaxone. Prophylactic antibiotics were given a single dose. A repeat dose can be given if the operation lasts for more than 3 hours or the bleeding is more than $1500 \mathrm{cc}$. The samples studied were classified as category $\mathrm{V}$ because the administration of parenteral antibiotics was continued after surgery even though there was no diagnosis of infection and the results of laboratory tests were within normal limits. ${ }^{20}$

In this research, the most frequent use of antibiotics was given empirically. The use of antibiotics for empiric therapy is the use of antibiotics in cases of infection where the cause of the bacteria is unknown. The aim of giving antibiotics for empiric therapy was to eradicate or inhibit the growth of bacteria that are suspected to be the cause of infection, before the results of microbiological examination are obtained. The route of empiric antibiotic administration that was recommended and the first choice for infection therapy was oral antibiotics. In moderate to severe infections, parenteral antibiotics can be considered. ${ }^{21}$ The duration of empiric antibiotics was given for a period of 48-72 hours. Furthermore, an evaluation must be conducted based on microbiological data and the patient's clinical condition and other supporting data. However, in this research, the use of antibiotics was mostly given parenterally, and this led to irrational administration of antibiotics. ${ }^{22}$

The irrational use of antibiotics in the sample of this research was also due to the existence of cheaper antibiotics, or it could be classified into category IV C. Antibiotics available in Indonesia can be in the form of generic drugs, trademark drugs, originator drugs or drugs that are still protected by rights. patent (patent drug). The price of antibiotics varies widely. The price of antibiotics with the same content can be up to 100 times more expensive than the generic one. Especially, parenteral preparations can be 1000 times more expensive than oral preparations with the same content. Expensive prescription of antibiotics, with prices beyond the financial limits of the patient will have an impact on the patient not buying antibiotics, resulting in the failure of therapy. No matter how precise the antibiotic is prescribed, if it is far from the patient's financial level, it would certainly not be useful. Cases with category IV in this research were the most because almost all patients received third generation cephalosporin antibiotics in parenteral preparations both as prophylactic and empirical therapy. ${ }^{23}$ 


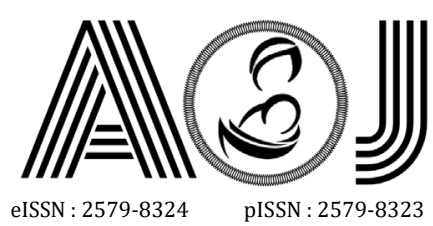

eISSN : 2579-8324
pISSN : 2579-8323

\section{The Evaluation PPRA Implementation}

Hospitals as health care facilities have the potential to be one of the places for the spread of resistant microbes. Therefore, the National Hospital Accreditation Standard (SNARS) Edition 1 that applied in January 2018 as a reference for hospital accreditation adds the Antimicrobial Resistance Control Program (PPRA). This causes that starting from 2018, all accredited hospitals in Indonesia have been required to have PPRA. Previously, several hospitals in Indonesia had implemented policies and programs related to the control of antimicrobial resistance, as well as Dr. M. Djamil Padang.

There are several elements of PPRA assessment according to SNARS Edition 1, such as the existence of regulations and programs regarding the control of antimicrobial resistance in hospitals according to statutory regulations, the involvement of hospital leaders in program planning, financial support from the hospital, the implementation of controlling the use of antibiotic therapy and surgical prophylaxis in the entire patient care process according to guidelines, and periodic PPRA activity reports from the Hospital Director to the Ministry of Health. ${ }^{24}$

The success of implementing PPRA in a hospital can be evaluated by analyzing the use of antibiotics qualitatively and quantitatively. In this research, there was no improvement in output in the use of antibiotics after the application of PPRA, in contrast to the research conducted by Hadi et al (2012). ${ }^{22}$ In a Regional General Hospital after PPRA implementation, $34.7 \%$ of antibiotic therapy were categorized as appropriate and $30.6 \%$ were given without indication.

Based on a qualitative analysis, it showed that there was a higher trend in the category that is still bad. Category V was higher in 2019 when compared to 2018. This was due to the policy made by PPRA in the guidance of using antibiotics in Dr. M. Djamil that only provided guidance on the use of prophylactic antibiotics, dis not discuss how to continue antibiotics, and there was no explanation regarding the indicators used to decide whether prophylactic antibiotics are continued with empiric antibiotics or there was no need for antibiotics afterwards.

There had not been an increase in the quality of antibiotic use according to the Gyssen line. This can be concluded that there was no significant change in the implementation of PPRA work. This indicated that PPRA at RSUP Dr. M. Djamil had not been going well. This was because the socialization of the antibiotic use policy had not been going well. Human resources including teams or committees such as the Antimicrobial Resistance Control Program (PPRA), Infection Prevention and Control (PPI), the Pharmacy and Therapy Committee (KFT), and clinical microbiology have not been going well. ${ }^{5}$

The implementation of intervention steps based on WHO recommendations in order to increase the success of drug use including antibiotics rationally has not worked well. For 


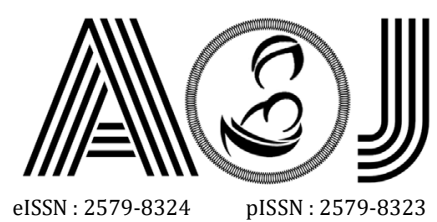

eISSN : 2579-8324
pISSN : 2579-8323

example, the application of clinical guidelines or Minimum Service Standards (SPM) that have not been revised periodically, monitoring, auditing, and feedback on policy implementation rational use of antibiotics that have not worked well.

\section{Conclusion}

There was a significant change of implementation of PPRA work on a qualitative analysis of antibiotic use.

\section{Suggestion}

Based on the discussion above, the researchers can reveal some suggestions, as follow:

1. PPRA is expected to make policy regarding the use of continued antibiotics after prophylactic antibiotics. Besides, there is no explanation regarding the indicators used to decide whether prophylactic antibiotics are continued with empiric antibiotics or there is no need for antibiotics afterwards.

2. PPRA is expected to make policy regarding limits on the use of empiric antibiotics, and the implementation of culture and sensitivity tests to prevent the use of resistant antibiotics.

3. PPRA is expected to be able to improve socialization of the policy on antibiotic use at RSUP M. Djamil. Thus, it can be implemented properly, so that all parties can use abtibiotics rationally.

4. The involvement of all party is expected including the team or committee of the Antimicrobial Resistance Control Program (PPRA), Infection Prevention and Control (PPI), the Pharmacy and Therapy Committee (KFT), and clinical microbiology conduct periodic evaluations, to be able to analyze the use of antibiotics at RSUP Dr. M. Djamil in order prevent the inaccuracy of using antibiotics.

\section{REFERENCES}

1. Peraturan Menteri Kesehatan Nomor 8 Tahun 2015 Tentang Program Pengendalian Resistensi Antimikroba di Rumah Sakit.

2. Rosdiana, D. Angraini, D. dkk. 2017. Peningkatan Rasionalitas Penggunaan Antibiotik Pasca Implementasi Kebijakan Penggunaan Antimikroba di RSUD Arifin Achmad Pekanbaru. Jurnal Kedokteran Brawijaya Vol. 30. (1) pp. 36-40.

3. Gyssens, IC., 2005. Audit for Monitoring the Quality of Antimicrobial Prsescription. Dalam: Gould, I.M., Van der Meer, penyunting, Antibiotik Policies: Theory and Practice, Kluwer Academic Publishers. New York. Hal. 197-226. 


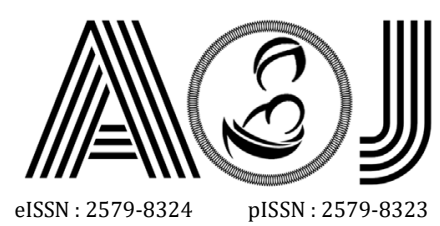

4. Lestari, E.S., Severin, J.A., et al. 2008. Antimicrobial resistance among commensal isolates of Escherichia coli and Staphylococcus aureus in thelndonesian population inside and outside hospitals. Eur J Clin Microbiol Infect Dis. Val. 27(1). Hal. 45-51.

5. Sari, Y. O. Dedy A., dan Anggun F. 2018. Evaluasi Penggunaan Antibiotik Pada Pasien Ulkus Diabetikum di Instalasi Rawat Inap (IRNA) Penyakit Dalam RSUP Dr. M. Djamil Padang. Jurnal Sains Farmasi dan Klinis Vol. 5 (2) pp. 102-111.

6. Suparyanto. (2011). Wanita Usia Subur dan Kanker Payudara. http//etd.eprints.detik.

7. Kristiani, F., Maksum R., dan Alfina R. 2019.Evaluasi Penggunaan Antibiotik Secara Kualitatif dan Analisis Efektivitas Biaya pada Pasien Pediatri di RSUP Fatmawati Jakarta.Jurnal Sains Farmasi dan Klinis Vol. 6 (1) pp 46-53.

8. Kasper, D.L., et al., 2005. Harrison's Principles of Internal Medicine. 16th ed. Mc Graw Hill, New York.

9. Weir CB, Le JK. Metronidazole. [Updated 2020 Jun 28]. In: StatPearls [Internet]. Treasure Island (FL): StatPearls Publishing; 2020 Jan-. diakses dari : https://www.ncbi.nlm.nih.gov/books/NBK539728

10. AMRIN - Study Group. 2005.Penggunaan antibiotik di RS Dr Soetomo Surabaya dan RSUP dr. Kariadi Semarang.

11. Yuniftiadi F. 2010.Kajian rasionalitas penggunaan antibiotik di intensive care unit RSUP Dr. Kariadi Semarang periode Juli-Desember 2009. Semarang: Universitas Dipenegoro

12. Febiana T. 2012. Kajian rasionalitas penggunaan antibiotik di intensive care unit RSUP Dr. Kariadi Semarang Periode Agustus- Desember 2011. Semarang: Universitas Dipenogoro

13. Theresia. 2011. Evaluasi Kualitatif Penggunaan Antibiotik di Departemen Ilmu Kesehatan Anak FKUI Rumah Sakit Cipto Mangunkusumo. [Tesis]. Jakarta: Fakultas Kedokteran Universitas Indonesia.

14. Peraturan Menteri Kesehatan Republik Indonesia Nomor 2406 Tahun 2011. Tentang Penggunaan Antibiotik. Jakarta.

15. Arumugham VB, Cascella M. 2020. Third Generation Cephalosporins. [Updated 2020 Jul 4]. In: StatPearls [Internet]. Treasure Island (FL): StatPearls Publishing; Available from: https://www.ncbi.nlm.nih.gov/books/NBK549881/

16. Gerber JS, Newland JG, Coffin SE, Hall M, Thurm C, Prasad PA, et al. 2010. Variability in Antibiotik Use at Children's Hospitals. Official Journal of The American Academy of Pediatrics. 126. Hal. 1067-1073.

17. Ashraf MM, Javed I, Aslam B, Khaliq T.2015. Cefixime; Disposition kinetics and bioavailability comparison of two formulations of cefixime in healthy adult male subjects. Professional Med J, vol. 22 (7). Hal. 959-965. 


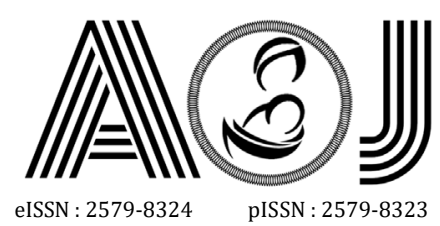

eISSN : 2579-832

18. Dertarani, V. 2009. Evaluasi Penggunaan Antibiotik Berdasarkan Kriteria Gyssens di Bagian IImu Bedah RSUP DR Kariadi. [Tesis]. Semarang: Fakultas Kedokteran UNDIP.

19. Pamela, D.S. 2011. Evaluasi Kualitatif Penggunaan Antibiotik Dengan Metode Gyssens Diruang Kelas 3 Infeksi Departemen IImu Kesehatan Anak Rscm Secara Prospektif. [Tesis]. Jakarta: Fakultas Kedokteran Universitas Indonesia.

20. Tjaniadi, $P$, Lesmana $M$, et.al. 2003. Antimicrobial resistance of bacterial pathogens associated with diarrheal patients in Indonesia, Am. J. Trop. Med. Hyg., Vol. 68 (6). Hal. 666-670.

21. Zakiya, N. M. 2016. Evaluasi Kualitas Penggunaan Antibiotik Pada Pasien Pasca Bedah Dengan Metode Gyssens di RSUD Bhakti Dharma Husada Surabaya Tahun 2016. [Skripsi]. Malang. Fakultas Kedokteran Dan IImu-IImu Kesehatan Universitas Islam Negeri Maulana Malik Ibrahim Malang

22. Hadi, U., Duerink, D.O., et al. 2008. Audit of antibiotik prescribing in two governmental teaching hospitals in Indonesia. Clinical Microbiology and Infectious Disease Journal. Vol. 14(7). Hal. 698-707.

23. Setiabudy, R. 2007. Pengantar Antimikroba. Farmakologi dan Terapi. Edisi kelima. Balai Penerbit FKUI. Jakarta. Hal. 585, 592-593.

24. Sutoto. dkk. 2018. Instrumen Survei Standar Nasional Akreditasi Rumah Sakit Edisi 1. Jakarta: Komisi Akreditasi Rumah Sakit . 